\title{
In-Tank Precipitation with Tetraphenylborate: Recent Process and Research Results \\ CDNF- $970962--$
}

by

D. D. Walker

Westinghouse Savannah River Company

Savannah River Site

Aiken, South Carolina 29808

M. J. Barnes

C. L. Crawford

R. A. Peterson

R. F. Swingle

S. D. Fink

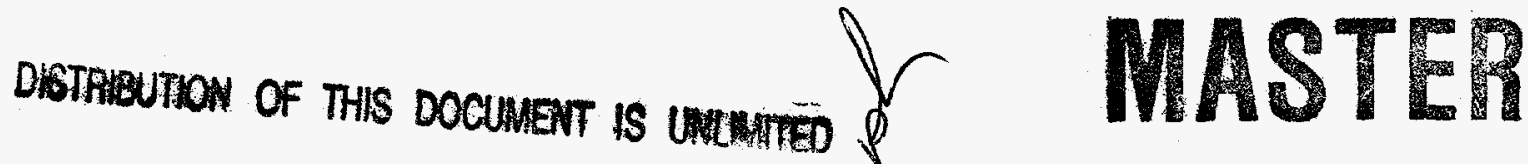

A document prepared for 214TH AMERICAN CHEMICAL SOCIETY NATIONAL MEETING at Las Vegas, NV, USA from $9 / 7 / 97-9 / 11 / 97$.

\section{DOE Contract No. DE-AC09-96SR18500}

This paper was prepared in connection with work done under the above contract number with the U.S.

Department of Energy. By acceptance of this paper, the publisher and/or recipient acknowledges the U.S. Government's right to retain a nonexclusive, royalty-free license in and to any copyright covering this paper, along with the right to reproduce and to authorize others to reproduce all or part of the copyrighted paper. 


\section{DISCLAIMER}

This report was prepared as an account of work sponsored by an agency of the United States Government. Neither the United States Government nor any agency thereof, nor any of their employees, makes any warranty, express or implied, or assumes any legal liability or responsibility for the accuracy, completeness, or usefulness of any information, apparatus, product, or process disclosed, or represents that its use would not infringe privately owned rights. Reference herein to any specific commercial product, process, or service by trade name, trademark, manufacturer, or otherwise does not necessarily constitute or imply its endorsement, recommendation, or favoring by the United States Government or any agency thereof. The views and opinions of authors expressed herein do not necessarily state or reflect those of the United States Government or any agency thereof. 


\section{DISCLAIMER}

Portions of this document may be illegible electronic image products. Images are produced from the best available original document. 


\section{DISCLATMER}

This report was prepared as an account of work sponsored by an agency of the United States Government. Neither the United States Government nor any agency thereof, nor any of their employees, makes any warranty, express or implied, or assumes any legal liability : or. -responsibility for the accuracy, completeness, or usefullness of any information, apparatus, product, or process disclosed, or represents that its use would not infringe privately ownod rights. Reference herein to any specific commercial product, process, or service by trade name, trademark, manufacturer, or otherwise does not necessarily constitute or imply its endorsement, recommendation, or favoring by the United States Government ar any agency thereof. The views and opinions of authors expressed herein do not nocessarily state or reflect those of the United States Govemment or any agency thereof.

This report has been reproduced directly from the best available copy.

Available to DOE and DOE contractors from the Office of Scientific and Technical Information. P.O. Box 62, Oak Ridge, TN 378331; prices available from (615) 57.6-8401.

Available to the public from the. National Technical. Information Service, U.S. Department of Commerce, 5285 Port Royal Road, Springfield, VA 22161. 


$$
\begin{aligned}
& \text { WSRC-MS-97-0363 } \\
& \text { Science and Tedindogy for } \\
& \text { Disposal of Radioactive } \\
& \text { Tant wastes }
\end{aligned}
$$

\title{
IN-TANK PRECIPITATION WITH TETRAPHENYLBORATE: RECENT PROCESS AND RESEARCH RESULTS
}

\author{
D. D. Walker, M. J. Barnes, C. L. Crawford, R. A. Peterson, \\ R. F. Swingle, and S. D. Fink \\ Westinghouse Savannah River Company \\ Savannah River Site \\ P. O. Box A \\ Aiken, SC 29802
}

\begin{abstract}
At the Savannah River Site (SRS), the In-Tank Precipitation (ITP) process uses sodium tetraphenylborate to decontaminate soluble waste by precipitating cesium-137. The first batch operations in October 1995 successfully decontaminated one-half million gallons of high-level waste producing 346,000 gallons of filtrate containing only $3 \mathrm{nCi}$ cesium- 137 per gram. During the precipitation and filtration, measured benzene generation fell well below safe limits. During a pause in the test sequence, the excess sodium tetraphenylborate decomposed. The decomposition occurred in highly alkaline solution in which tetraphenylborate was previously shown to be stable. The reaction at high $\mathrm{pH}$ appears catalyzed by trace amounts of transition metals in the waste. The reaction proceeded by successive removal of phenyl groups, ending in borate ion with major products benzene ( $87 \%$ yield), phenol $(7 \%)$, and biphenyl $(4.5 \%)$. The benzene remained in the slurry and was released under a nitrogen overblanket during carefully controlled operations of the slurry pumps in the tank. Subsequent experiments demonstrated transition metals and excess sodium tetraphenylborate required for the rapid decomposition reaction. The rate of benzene formation increases with temperature and under anoxic conditions.
\end{abstract}

\section{IN-TANK PRECIPITATION}

The ITP process at SRS prepares high-level radioactive waste for vitrification in the Defense Waste Processing Facility (DWPF). ${ }^{1-4}$ Figure 1 diagrams the ITP process. The water-soluble radioactive waste at SRS is currently stored as damp saltcake and concentrated salt solution in thirty-two 4.9-million-liter carbon steel tanks. The first step in the disposal of the waste involves dissolving the saltcake using water agitated by long-shaft slurry pumps. Upon saturation, the facility removes the solution in batches and sends the liquid to a processing tank. Table 1 shows the major soluble components of the waste and their nominal concentration in the salt solution feed to the ITP process. In addition to the major soluble components, small amounts of transition metals enter the processing tank in two forms. 
Table 1. Approximate Chemical Composition of Salt Solution Feed to the In-Tank Precipitation Process

\begin{tabular}{ll}
\hline Component & Concentration (molar) \\
\hline $\mathrm{Na}^{+}$ & 7.00 \\
$\mathrm{~K}^{+}$ & 0.02 \\
$\mathrm{NO}_{3}^{-}$ & 2.70 \\
$\mathrm{NO}_{2}^{-}$ & 1.00 \\
$\mathrm{AlO}_{2}^{-}$ & 0.40 \\
$\mathrm{CO}_{3}^{2-}$ & 0.20 \\
$\mathrm{SO}_{4}^{2^{-}}$ & 0.20 \\
$\mathrm{OH}^{-}$ & 1.90 \\
$\mathrm{Cs}$ (all isotopes) & $7 \times 10^{-4}$ \\
$\mathrm{Cs}-137$ & $1 \mathrm{Ci} / \mathrm{L}$
\end{tabular}

First, these metals may exist as soluble species; but, due to the high $\mathrm{pH}$ of the waste, their concentrations remain less than a few parts per million. Second, the metals exist as insoluble metal hydroxide and oxide particles (called "sludge") entrained in the soluble waste solution. The process can concentrate entrained sludge to tenths of a weight percent of the slurry.

The facility dilutes the concentrated salt solution to approximately $5 \mathrm{M}$ sodium ion. Cesium137 and strontium-90 removal uses two specialty chemicals, sodium tetraphenylborate (NaTPB)

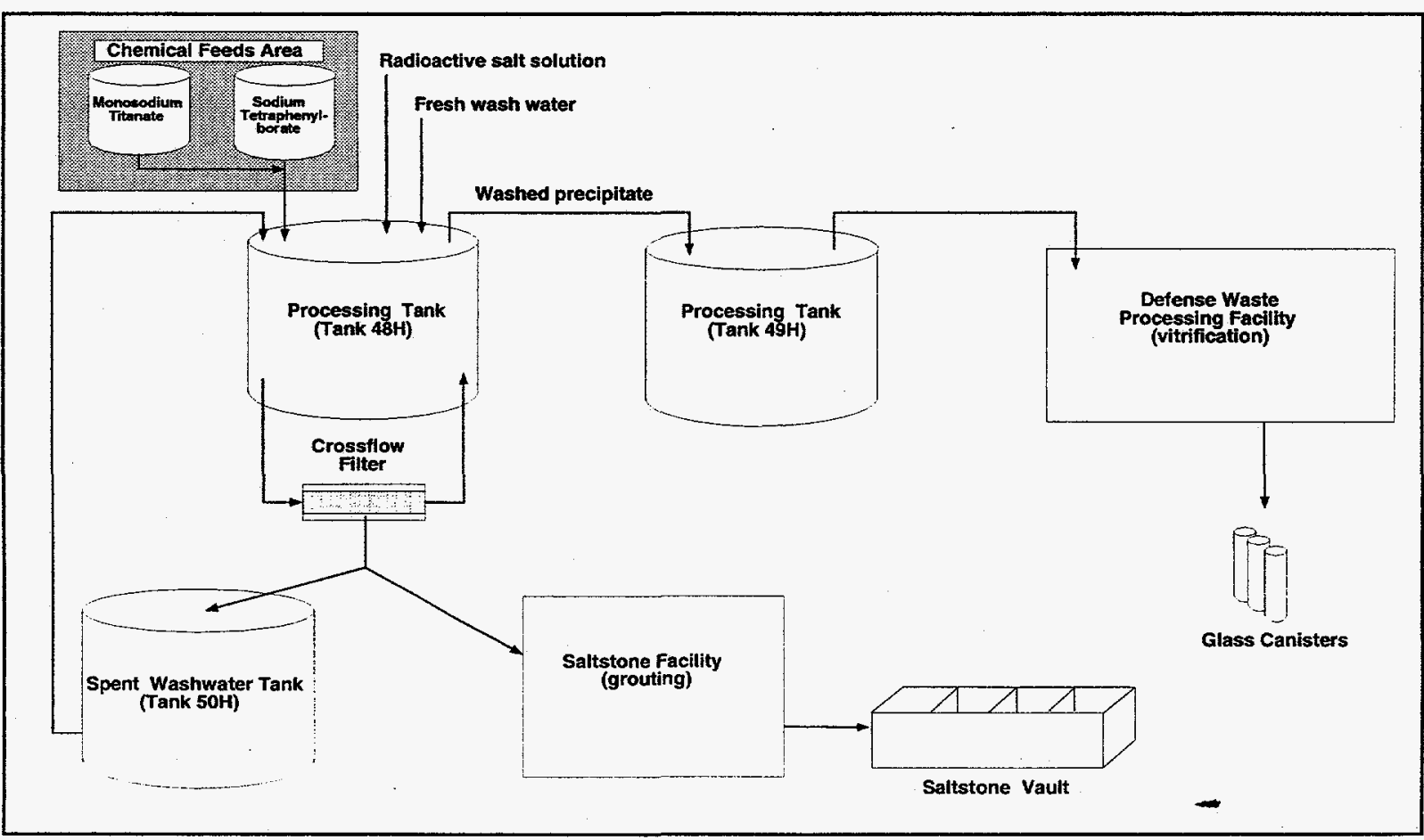

Figure 1. Diagram of the In-Tank Precipitation Process 
and monosodium titanate (MST). Sodium tetraphenylborate precipitates cesium and potassium. The titanate removes strontium through ion exchange while adsorbing uranium and plutonium. The major chemical reactions follow:

$$
\begin{aligned}
& \mathrm{Cs}^{+}+\mathrm{B}\left(\mathrm{C}_{6} \mathrm{H}_{5}\right)_{4}^{-}====>\mathrm{CsB}\left(\mathrm{C}_{6} \mathrm{H}_{5}\right)_{4}(\mathrm{~s}) \\
& \mathrm{K}^{+}+\mathrm{B}\left(\mathrm{C}_{6} \mathrm{H}_{5}\right)_{4}^{-}====>\mathrm{KB}\left(\mathrm{C}_{6} \mathrm{H}_{5}\right)_{4}(\mathrm{~s}) \\
& \mathrm{Sr}^{2+}+2 \mathrm{NaTi}_{2} \mathrm{O}_{5} \mathrm{H}(\mathrm{s}) \Longrightarrow \mathrm{Sr}\left(\mathrm{Ti}_{2} \mathrm{O}_{5} \mathrm{H}\right)_{2}(\mathrm{~s})+2 \mathrm{Na}^{+}
\end{aligned}
$$

Under expected operating conditions, this process will reduce the cesium-137 concentration to less than $10 \mathrm{nCi}$ per milliliter of solution. Approximately $99 \%$ (by weight) of the tetraphenylborate precipitate exists as potassium tetraphenylborate (KTPB) with $1 \%$ as cesium tetraphenylborate (CsTPB). Crossflow filters concentrate and wash the insoluble species. Decontaminated filtrate transfers to the Saltstone Facility that mixes the filtrate with pre-blended slag, fly ash, and cement and then pumps the slurry into concrete vaults for disposal. The resulting grout is a non-hazardous lowlevel radioactive waste form that is disposed in a low-level radioactive industrial waste landfill permitted by the South Carolina Department of Environmental Concerns. After washing to remove nonradioactive soluble sodium salts, the concentrated tetraphenylborate solids and MST transfer to a storage tank until processed for vitrification.

A full-scale demonstration of the process using 427,000 gallons of soluble high-level radioactive waste successfully completed in $1983 .^{2}$ During the demonstration, benzene produced from decomposition of tetraphenylborate exceeded amounts predicted from laboratory testing. Subse-

quent studies of tetraphenylborate decomposition mechanisms $\mathrm{s}^{5-8}$ resulted in increased estimates of benzene production and required modifications to the processing tank ventilation system. To maintain safety, the facility inerts the process and storage tank vapor spaces by injecting nitrogen gas to dilute oxygen below the concentration required for combustion. In addition, the ventilation system capacity maintains the combustible components (i.e., benzene and hydrogen from radiolysis) below the combined lower flammability limits.

\section{ITP First Batch Results}

On September 1, 1995, the Department of Energy authorized startup of the process. Special monitoring equipment and procedures in place for the first batch operations allowed monitoring of combustible gases in the tank vapor space. The equipment included two sampling poles placed into risers on opposite sides of the tank. The poles provided vapor samples for gas chromatographic analysis of benzene and hydrogen. Several pump mixing tests occurred to determine the distribution of combustible gases within the tank vapor space under various mixing, temperature, and ventilation conditions. Besides combustible gas concentrations, facility personnel monitored several other tank variables such as temperature of the liquid phase and vapor phase, oxygen concentration in the vapor space, waste volume, and ventilation flowrate.

Beginning on September 2 and continuing through September 29, personnel added sodium tetraphenylborate solution to the tank. The tank contained the tetraphenylborate slurry from the 1983 full-scale demonstration and radioactive waste added during the intervening years. Table 2 lists the components and composition of the first precipitation batch. The additions included NaTPB in excess of the amount required to precipitate the soluble potassium ion to ensure complete and rapid precipitation of the cesium-137. Since NaTPB is soluble to about 0.002 molar at $5 \mathrm{M} \mathrm{Na}{ }^{+}$and $35^{\circ} \mathrm{C}$ (the approximate tank temperature), the majority of the excess NaTPB precipitated as soluble NaTPB(s) or as mixed crystals of sodium, potassium, and cesium tetraphenylborate. Table 3 shows a calculated material balance for the sodium tetraphenylborate added to the tank. The excess solid NaTPB weighed approximately $10,500 \mathrm{~kg}$. 
Table 2. Composition of the First Precipitation Batch

\begin{tabular}{|c|c|}
\hline & Volume (gal) \\
\hline Precipitate slurry from 1983 demonstration & 11,000 \\
\hline Radioactive waste & 455,000 \\
\hline Sodium tetraphenylborate solution $(0.57 \mathrm{M})$ & 37,300 \\
\hline Monosodium titanate slurry & 2,000 \\
\hline Total: & 505,000 \\
\hline Component & Concentration (molar) \\
\hline $\mathrm{Na}^{+}$ & 5.00 \\
\hline $\mathrm{NO}_{3}^{-}$ & 0.60 \\
\hline $\mathrm{NO}_{2}^{-}$ & 0.80 \\
\hline $\mathrm{A} 1 O_{2}^{-}$ & 0.20 \\
\hline $\mathrm{CO}_{3}^{2^{-}}$ & 0.26 \\
\hline $\mathrm{SO}_{4}^{2^{-}}$ & 0.01 \\
\hline $\mathrm{OH}^{-}$ & 2.70 \\
\hline Cs-137 & $3 \mathrm{nCi} / \mathrm{g}$ \\
\hline Density & $1.2 \mathrm{~g} / \mathrm{mL}$ \\
\hline
\end{tabular}

Precipitation of cesium-137 completed within two days of the final NaTPB addition and reached concentrations an order of magnitude lower than disposal requirements. Following the last NaTPB addition, personnel mixed the tank contents by operating four slurry pumps at maximum speed for two days. Each slurry pump jets approximately $1000 \mathrm{gpm}$. After two days of mixing, the soluble cesium concentration reached $3 \mathrm{nCi} / \mathrm{g}$, well within the acceptable process requirements $(<45 \mathrm{nCi} / \mathrm{g})$ and similar to the concentration found during the 1983 full-scale process demonstration.

During this time period, personnel did not operate the tank cooling system, and the energy input from running the slurry pumps heated the tank contents. Figure 2 graphs the waste temperature. The increase from $33^{\circ} \mathrm{C}$ to $38^{\circ} \mathrm{C}$ starting on September 30,1995 , reflects pump mixing.

Between October 9, 1995, and December 1, 1995, three pump and ventilation tests occurred in the tank. These tests monitored combustible gases within the tank vapor space under a variety of tank conditions such as the number of pumps operating and pump speed, ventilation rate, volume of waste in the tank, and temperature differential between the waste and tank ceiling. Table 4 provides an outline of the test sequence.

Crossflow filters separated the highly radioactive precipitate from the decontaminated salt during the intervals between the first and second pump/ventilation tests and again between the second and third tests. No difficulties occurred during production of 346,000 gallons of decontaminated filtrate in the two filter runs. At the end of the second filtration stage, the tank contained 165,000 gallons of slurry at approximately $4 \mathrm{wt} \%$ solids. 
Table 3. Material Balance for Sodium Tetraphenylborate in Batch 1

$\begin{array}{lrr}\text { NaTPB added: } & 37,300 \text { gal @ } 0.57 \mathrm{M} & 80,500 \text { moles } \\ \mathrm{K}^{+} \text {precipitated: } & 466,000 \text { gal @ } 0.027 \mathrm{M} & 47,600 \text { moles } \\ \mathrm{Cs}^{+} \text {precipitated: } & 466,000 \mathrm{gal} @ 3 \times 10^{-5} \mathrm{M} & 60 \text { moles } \\ \text { Soluble TPB: } & 505,000 \mathrm{gal} @ 0.003 \mathrm{M} & 5,700 \text { moles } \\ \text { Insoluble NaTPB: } & 27,140 \text { moles } & (9,300 \mathrm{~kg})\end{array}$

\section{Benzene Generation}

Figure 3 shows the benzene concentration in the tank exhaust during the ITP Batch 1 operations. With the tank quiescent, the gas chromatographs detected $<20 \mathrm{ppm}$ benzene in the tank vaporspace when the ventilation system operated $(700 \mathrm{scfm})$. During a test of oxygen ingress when interrupting the tank ventilation system, benzene in the vapor space gradually increased to $20 \mathrm{ppm}$ over 6 days. With the ventilation system operating, mixing the waste with slurry pumps increased the rate of mass transfer of benzene to the vapor space. Benzene concentrations were measurable until the accumulated benzene depleted from the waste.

Despite the presence of the tetraphenylborate precipitate from the 1983 full-scale demonstration (approximately 8,000 kg), personnel measured less than $1 \mathrm{ppm}$ benzene in the tank ventilation prior to addition of NaTPB during September 1995. Each truckload addition of NaTPB included tank mixing by operating slurry pumps. Largely due to the inventory in the NaTPB solutions, small amounts of benzene, evaporated into the tank vapor space. During this period, benzene concentrations in the tank vapor space peaked at $15-30 \mathrm{ppm}$.

During October and November 1995, personnel observed gradually increasing amounts of benzene during pump operations. During the three pump runs, benzene peaked at $60 \mathrm{ppm}, 160 \mathrm{ppm}$, and $320 \mathrm{ppm}$. The increase in the peak concentration reflected in part the decreasing waste volume in the tank and more efficient mixing by the pumps. The benzene generation rate from decomposition of tetraphenylborate also apparently increased during this time period.

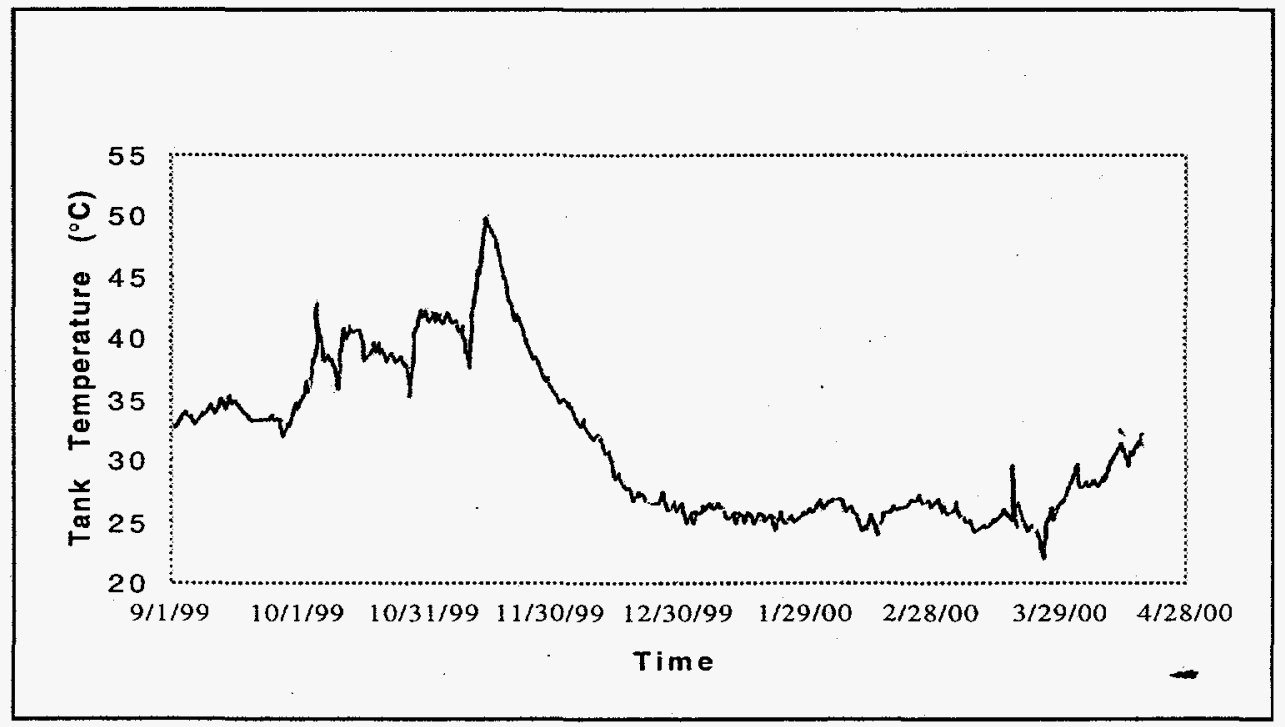

Figure 2. Waste Temperature in the Processing Tank 


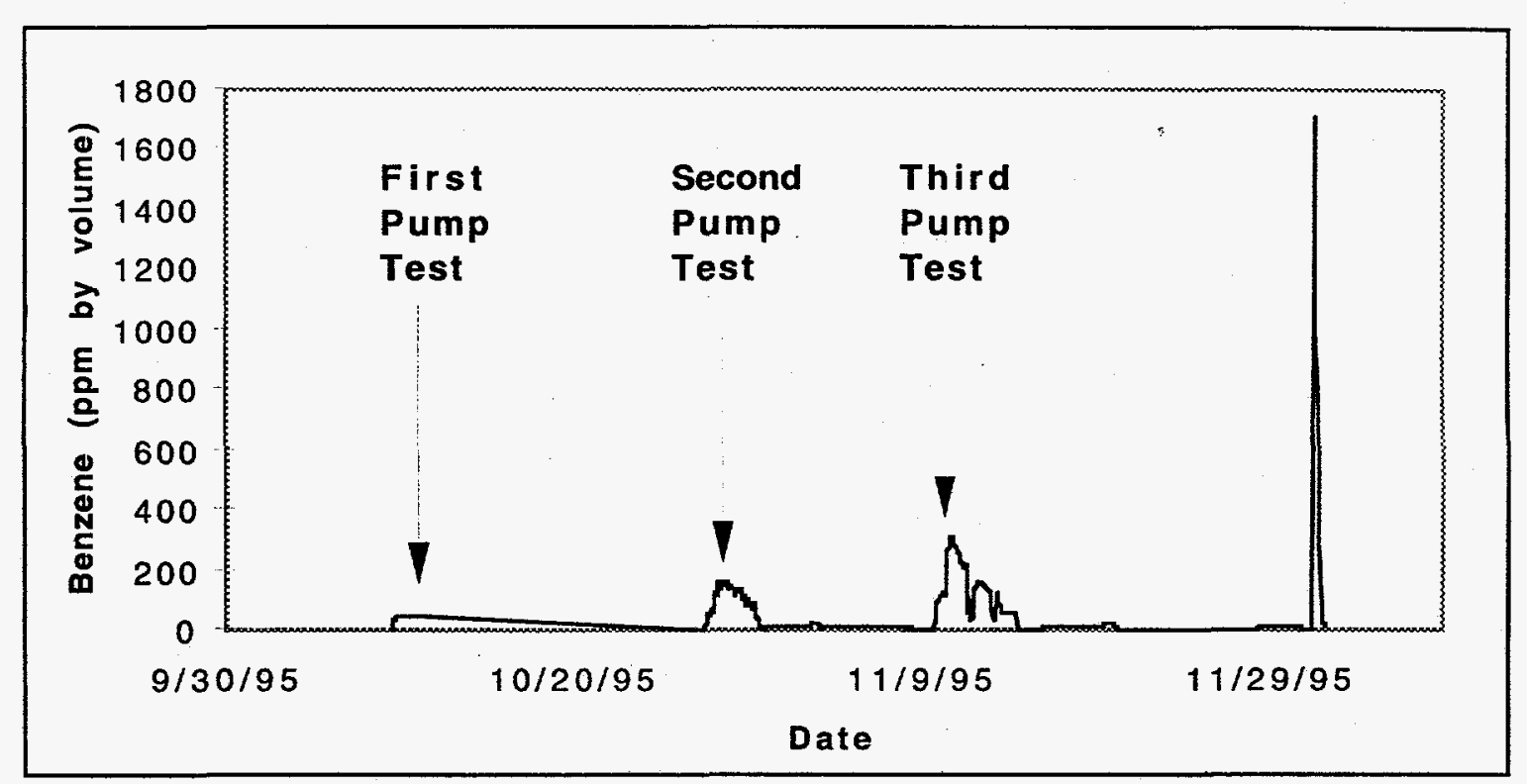

Figure 3. Benzene Concentrations in the Vapor Space of the Processing Tank During Operations

In mid November 1995 , the waste temperature increased to $52^{\circ} \mathrm{C}$ due to operation of the slurry pumps. This was the highest temperature attained in the tank during the first batch. After reaching this temperature, personnel did not mix the tank contents again until December 1, 1995, after the temperature decreased to $30^{\circ} \mathrm{C}$. On December 1 , all four slurry pumps operated for approximately 3.5 hours. Personnel halted all pump operations due to high $(2,000 \mathrm{ppm})$ benzene concentrations in the vapor space (approximately $15 \%$ of the LFL). The facility followed this event with periodic pump operation to deplete the benzene from the tank. The benzene depletion runs continued through June 1996 and included a three-month quiescent period from January 3 to March 5, 1996, to allow installation of a backup nitrogen ventilation system. Throughout these depletion runs, personnel controlled the rate of benzene evaporation through the number and speed of the pumps operated. By continuously ventilating the tank, personnel maintained the tank vapor space inerted with nitrogen and the combustibles below $30 \%$ of the composite LFL. At no time was the tank vapor space capable of supporting combustion due to both insufficient fuel and insufficient oxidant.

Table 4. Outline of Test Sequence

Dates

9/2/95-9/30/95

$9 / 30-10 / 2$

$10 / 3$

10/9-10/12

$10 / 20-10 / 25$

$10 / 26-10 / 29$

$11 / 2-11 / 7$

$11 / 9-11 / 13$

$11 / 15-11 / 30$

$12 / 1$

12/8/96-6/96
Operation or Test

\section{Add NaTPB}

Tank mixing (42 hours)

Decontamination verified

First pump test; pumps operated for 48 hours

First filtration; 165,000 gallons of decontaminated solution removed

Second pump test; pumps operated for 64 hours

Second filtration; 181,000 gallons of decontaminated solution removed

Third pump test; pumps operated to increase waste temperature to $54^{\circ} \mathrm{C}$

Ventilation test; vapor space monitored for two weeks before starting pumps

Pumps restarted to mix tank prior to sampling slurry

High benzene concentrations were found

Pumps operated intermittently to deplete benzene 


\section{Tetraphenylborate Decomposition}

Following the December 1 observation of high concentrations of benzene, personnel sampled the tank to determine changes in the chemical composition. At that time, cesium-137 remained precipitated with excess sodium tetraphenylborate present, but the concentration of phenol, phenylboronic acid (1PB), and soluble boron had increased significantly. These concentrations, coupled with the high benzene concentrations, indicated decomposition of some of the tetraphenylborate. Figure 3 gives analyses of samples taken every week or two to monitor the status of the tank chemistry.

By December 18, the excess NaTPB decomposed, and the soluble cesium-137 concentration began to increase. However, at this time, the rate of reaction sharply decelerated. Figure 4 shows the changes in the phenol, soluble boron, and 1PB concentrations. All increased sharply during November but slowed considerably thereafter. Based on this evidence, the majority of the decomposition occurred between November 5 and December 18 .

During the first batch operations, the free hydroxide ion concentration did not change appreciably. The concentration remained at $2.5 \pm 0.2$ molar between October 1995 and January 1996.

Table 5 gives a material balance for the decomposition through July 1996. The authors calculated the benzene released during the depletion runs was from the benzene and ventilation flow measurements. Benzene was the major decomposition product $(87 \%)$ and significant amounts of phenol (7\%) and biphenyl (4.5\%) formed. A minor amount of terphenyl $(0.3 \%)$ also formed. The close balance between products and loss of sodium tetraphenylborate suggests that the rapid decomposition reaction principally involves only the more soluble tetraphenylborate compound.

\section{RESULTS OF INVESTIGATIONS OF TETRAPHENYLBORATE DECOMPOSITION}

Tetraphenylborate ion exhibits instability in acidic solution but remains stable in strongly alkaline solutions. ${ }^{7-9}$ Copper catalyzes the decomposition in aqueous acid, but the reaction proceeds rapidly only below $\mathrm{pH} 12.8$ Copper catalysis does not account for the rapid reaction observed in the presence of $2.5 \mathrm{M}$ hydroxide ion during the ITP Batch 1. Laboratory experiments with radioactive

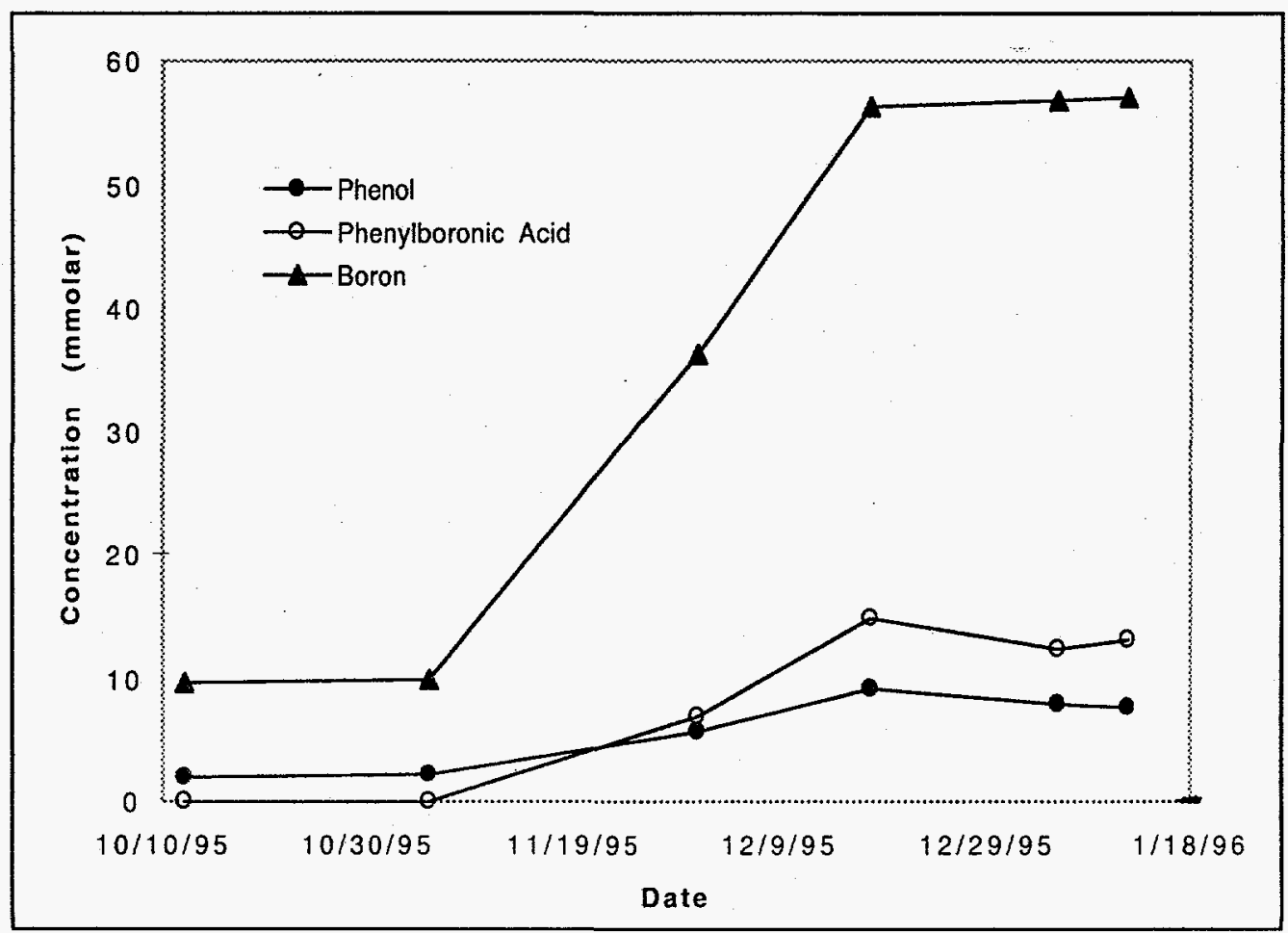

Figure 4. Changes in Processing Tank Composition 
Table 5. Material Balance for Decomposition Products through June 28, 1996

\begin{tabular}{|c|c|c|}
\hline Decomposed Solids & \multicolumn{2}{|c|}{ Equivalent Benzene (mo } \\
\hline NaTPB solids & & 108,600 \\
\hline NaTPB solution & & 7,200 \\
\hline KTPB & & 300 \\
\hline \multirow[t]{2}{*}{ CsTPB } & & $<1$ \\
\hline & Total: & 116,100 \\
\hline \multicolumn{3}{|l|}{ Products } \\
\hline Benzene & & 106,300 \\
\hline Phenylboronic acid & & 900 \\
\hline Phenol & & 8,700 \\
\hline Biphenyl & & 5,500 \\
\hline Terphenyl & & 400 \\
\hline & Total: & 121,800 \\
\hline
\end{tabular}

waste and simulants indicate that the rapid high $\mathrm{pH}$ reaction, which occurred in the ITP processing tank involved catalysis by trace amounts of transition metals present in the waste, was affected by the anoxic conditions and was enhanced by higher temperatures.

The authors used types of experiments to investigate the reaction. The first type measured benzene generated from decomposition of tetraphenylborate using waste from ITP Batch 1 and other sources to determine the response to the following variables; temperature, presence of sludge, and air/nitrogen. These tests stirred portions of waste held at constant temperature while purging the airspace above the waste with air or nitrogen. The experiments measured the purge gas stream for benzene for two to eight weeks. The second type of experiment use non-radioactive simulants incubated in steel containers, unstirred under air or nitrogen. Periodically, researchers mixed the slurry and sampled for analysis for benzene, phenol, and phenylboronic acid. These tests lasted two weeks at $70^{\circ} \mathrm{C}$. Table 6 shows the simulant composition. The simulant contained the major soluble components, tetraphenylborate solids, monosodium titanate, and sludge solids representative of ITP Batch 1.

Table 7 lists results from the benzene measurements in the first type of experiment. This data indicates sludge components of the waste are a major factor in producing high benzene generation rates. In addition, higher temperatures and nitrogen inerting increase benzene formation rates. These experiments did not measure loss of tetraphenylborate, so differences in benzene generation rate could reflect changes in product distribution rather than changes in rate.

Results using the second experimental procedure confirmed both sludge and excess NaTPB are required for the rapid decomposition reaction. Figure 5 shows the effect of sludge. The difference in reactivity between the control slurry without sludge and the slurry with sludge appears dramatic and indicates that one or more components of the sludge cause the rapid decomposition. The combined yields of benzene, phenylboronic acid, and phenol after 12 days confirmed that more than $50 \%$ of the excess NaTPB decomposed. In the control experiment without sludge, less than $1 \%$ decomposed. The drop in phenylboronic acid concentration reflects its decomposition to benzene and borate ion.

Figure 6 shows results from a similar slurry with sludge but without excess NaTPB at the start of the experiment. The experiment held potassium tetraphenylborate slurry was at $70^{\circ} \mathrm{C}$ for three weeks with only slight increases in reaction products. On the twenty-first day, personnel added excess NaTPB. During the next 13 days, the benzene and yield indicated $100 \%$ of the NaTPB decomposed. The material balance again showed that little or no KTPB decomposed. 


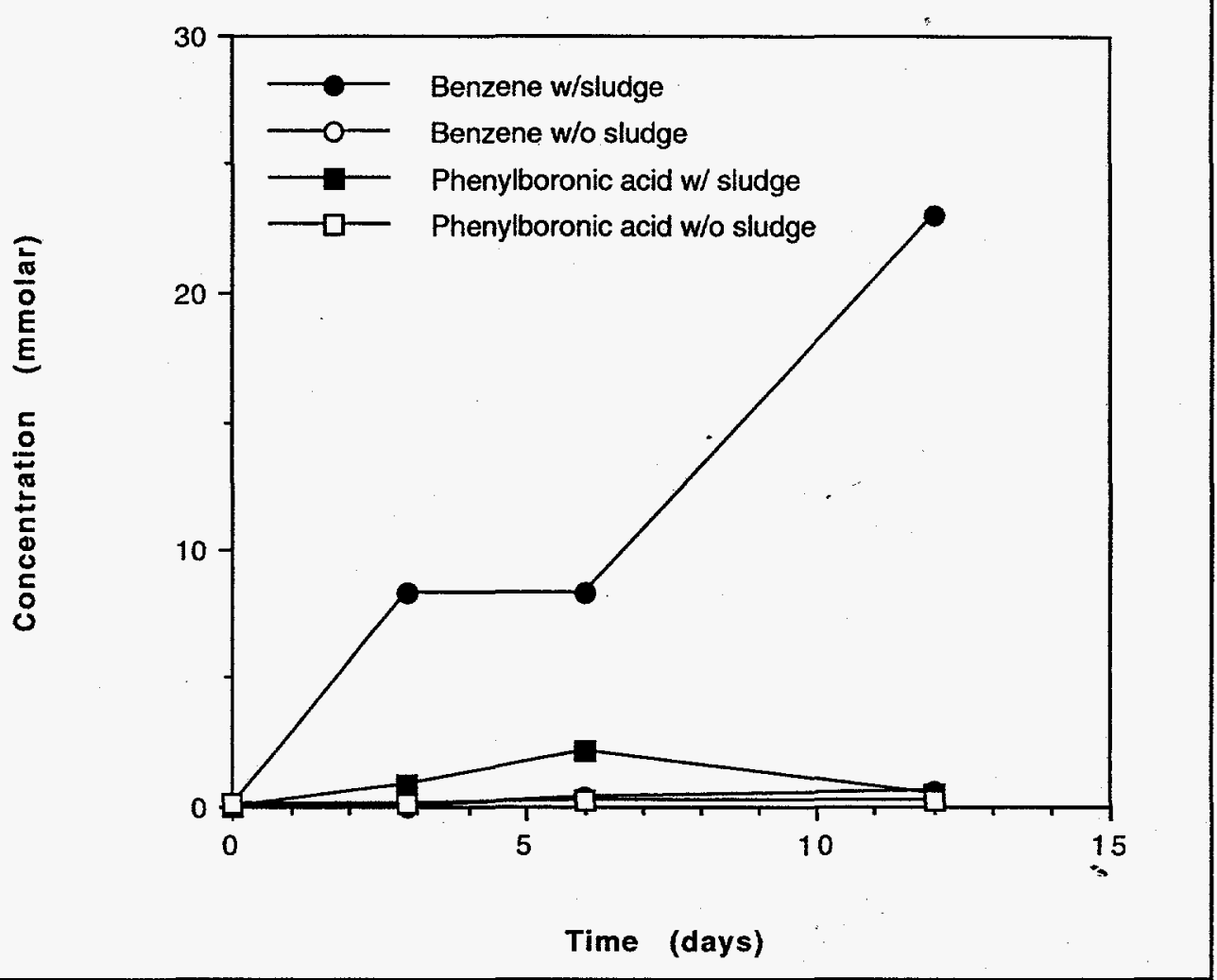

Figure 5. Effect of Sludge on Tetraphenylborate Decomposition

\section{SUMMARY}

The ITP process first batch operations in 1995-96 successfully decontaminated a 505,000 gallon batch of soluble radioactive waste. Filtration of the slurry produced 346,000 gallons of decontaminated salt solution subsequently made into saltstone. During the precipitation and filtration, personnel measured benzene generation in the processing tank well within safe limits. During a pause in the test sequence, the excess sodium tetraphenylborate decomposed, yielding benzene as the major product. The benzene remained in the slurry and released during deliberate and controlled operation of the slurry pumps in the tank. Laboratory studies indicate that the decomposition reaction appears catalyzed by trace transition metal species at high $\mathrm{pH}\left(2.5 \mathrm{M} \mathrm{OH}^{-}\right)$. The rate of the benzene formation increases with temperature and anoxic conditions. Work continues to measure detailed kinetic parameters.

\section{EXPERIMENTAL}

Personnel used the following instruments during the ITP Batch 1 processing. Type J thermocouples $\left( \pm 2.2^{\circ} \mathrm{C}\right)$ measured waste temperatures in at several location in the processing tank. A Kurz Instruments Model \#IK EVA 4200 flowmeter measured the ventilation flow on the outlet duct. A sampling system diverted a portion of the ventilation flow to a gas chromatograph s system composed of a drying system followed by a Microsensor Technology, Inc., gas chromatograph, Model M200 with thermal conductivity detector. The gas chromatograph separated hydrogen, oxygen, and nitrogen on an MS5A column with argon carrier gas and benzene on an OV73 column with helium carrier gas. A Hewlett Packard High Performance Liquid Chromatograph with a $2.1 \times 250 \mathrm{~mm}$ Dychrom 
Table 6. Composition of Simulant Slurry

Major Soluble (molar)

$\begin{array}{lrrr}\mathrm{Na}^{+} & 4.700 & \mathrm{SO}_{4}^{2-} & 0.010 \\ \mathrm{OH}^{-} & 2.700 & \mathrm{CO}_{3}^{2-} & 0.190 \\ \mathrm{NO}_{3}^{-} & 0.690 & \mathrm{Cl}^{-} & 0.014 \\ \mathrm{NO}_{2}^{-} & 0.700 & \mathrm{~F}^{-} & 0.008 \\ \mathrm{AlO}_{2}^{-} & 0.117 & \mathrm{PO}_{4}^{3^{-}} & 0.006\end{array}$

$\underline{\text { Trace Soluble }(\mathrm{mg} / \mathrm{L})}$

$\begin{array}{lccc}\text { Cr(VI) } & 73 & \text { Sn(IV) } & 2.3 \\ \text { Si(IV) } & 18 & \text { Se(VI) } & 0.8 \\ \text { Mo(VI) } & 12 & \text { As(IV) } & 0.1 \\ \text { Zn(II) } & 7.7 & & \end{array}$

Insoluble (wt \%)

$\begin{array}{llrl}\text { KTPB } & 4.0 & \text { MST } & 0.2 \\ \text { NaTPB } & 0.6 & \text { Sludge } & 0.2\end{array}$

Sludge (wt \% of dried sludge)

$\begin{array}{lrrrrr}\mathrm{Fe} & 28.8 & \mathrm{~Pb} & 0.3 & \mathrm{Ru} & 0.23 \\ \mathrm{Mn} & 5.9 & \mathrm{Zn} & 0.2 & \mathrm{Pd} & 0.11 \\ \mathrm{Al} & 4.8 & \mathrm{Cr} & 0.2 & \mathrm{Rh} & 0.06 \\ \mathrm{Ni} & 2.5 & \mathrm{Cu} & 0.1 & & \\ \mathrm{Zr} & 2.5 & \mathrm{Mg} & 0.1 & & \end{array}$

Chemosorb 5-ODS-UH column measured phenylboronic acid, phenol, biphenyl, and terphenyl using acetonitrile-water eluent. Personnel filtered slurry samples and analyzed the aqueous filtrate for phenol and phenylboronic acid. Personnel extracted slurry samples with hexane then analyzed the hexane for biphenyl and terphenyl. A high-purity germanium gamma spectroscopy system operated through a Canberra Genie PC software interface measured cesium- 137 concentrations in $3 \mathrm{~mL}$ samples. An ARL 3580 Inductively Coupled Plasma Emission Spectrometer measured boron concentrations. In laboratory experiments, an $\mathrm{HNU}$, Inc., Model 301 gas chromatograph fitted with a $10.2 \mathrm{eV}$ photoionization detector and a 1/8 in. $\times 3 \mathrm{ft}$ packed column of $3 \%$ SP-2100 on 100/120 mesh Supelcoport at $55^{\circ} \mathrm{C}$ measured benzene. The nitrogen carrier gas flow was $20 \mathrm{~mL} / \mathrm{min}$. Personnel analyzed samples by placing an aliquot of slurry $(1 \mathrm{~mL})$ into a large gas bulb $(1 \mathrm{~L})$, allowing the benzene to evaporate into the airspace and injecting a portion of the airspace by syringe directly into the GC.

Personnel prepared simulant slurries from reagent grade chemicals except for sodium tetraphenylborate. AFF, Inc., Atlanta, Georgia, produced the sodium tetraphenylborate as a $0.55 \mathrm{M}$ solution containing $0.1 \mathrm{M} \mathrm{NaOH}$. The original NaTPB solution was spray-dried, stored as a powder, then redissolved in water for use in ITP Batch 1. Laboratory experiments used $\overline{\mathbf{a}}$ portion of the solution. 
$\underline{\text { Effect of solids }\left(40^{\circ} \mathrm{C}\right)^{*}}$

Benzene Generation

Solids

$\mu \mathrm{g}^{-1} \mathrm{Lh}^{-1}$

None

3

$1.3 \mathrm{wt} \% \mathrm{NaTPB}$

40

3 wt \% NaTPB and

340

$0.2 \mathrm{wt} \%$ sludge**

Effect of temperature and purge gas***

Change in

\begin{tabular}{lllc} 
Initial & Final & & Benzene Generation(\%) \\
\cline { 1 - 1 } $40^{\circ} \mathrm{C}$ & $50^{\circ} \mathrm{C}$ & +253 \\
$50^{\circ} \mathrm{C}$ & & $40^{\circ} \mathrm{C}$ & -49 \\
air & nitrogen & +192 \\
nitrogen & air & -60 \\
$40^{\circ} \mathrm{C}$, air & $50^{\circ} \mathrm{C}$, nitrogen & +802
\end{tabular}

* Solution phase of Batch 1 filtrate taken November 10, 1995, saturated with NaTPB (0.003 M). The purge gas was air.

** Sludge solids include monosodium titanate and metal oxides/hydroxides isolated from ITP Batch 1. CsTPB and KTPB removed by dissolution in acetonitrile.

*** Solution phase of Batch 1 filtrate taken November 10, 1995. Solids included 3 wt $\%$ NaTPB and 0.2 or 0.5 wt \% sludge.

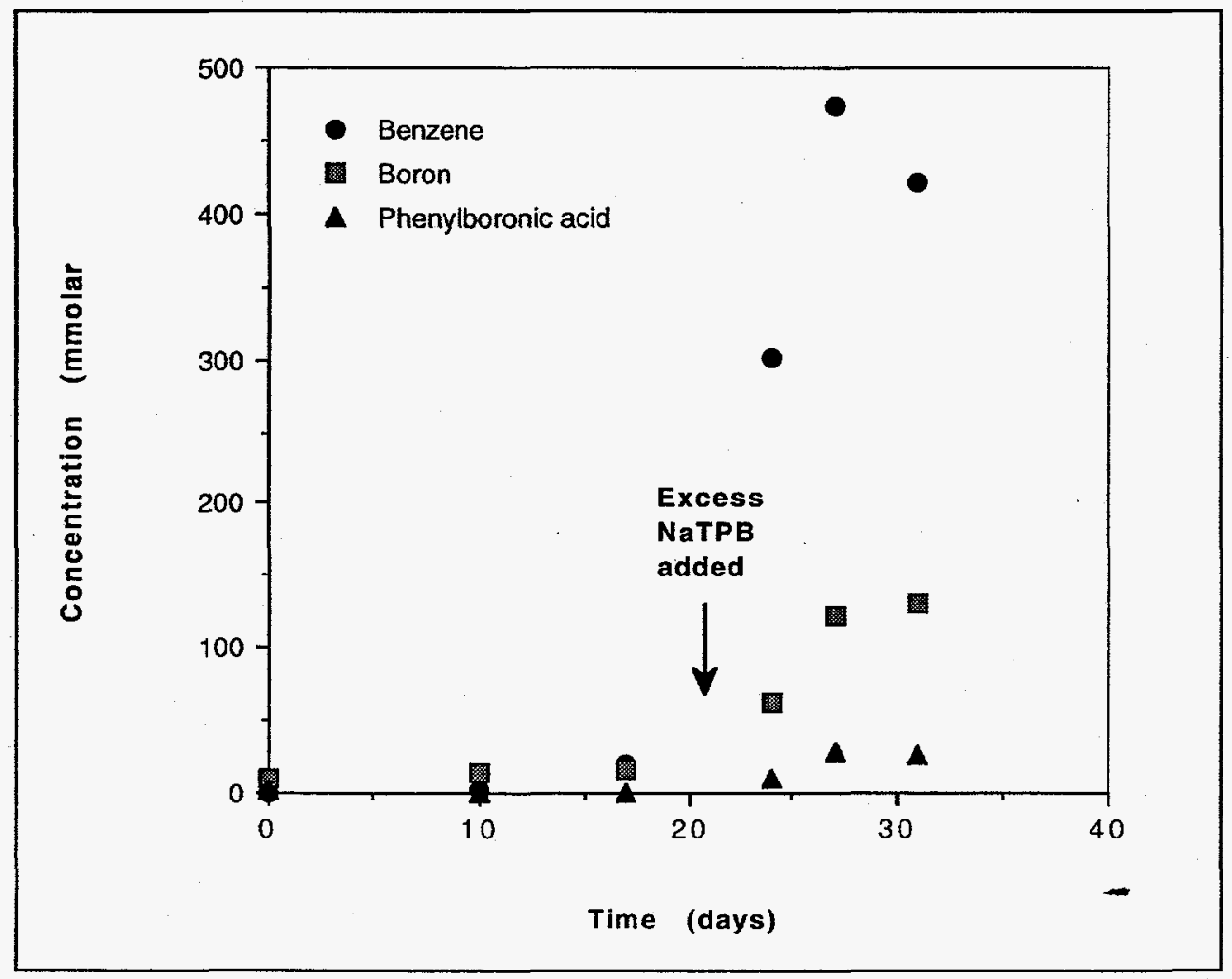

Figure 6. Effect of Excess NaTPB on Decomposition 
The laboratory tests with radioactive waste samples used 50 to $100 \mathrm{~mL}$ aliquots in glass vessels (250-mL internal volume). Water baths maintained constant temperature $\left( \pm 2^{\circ} \mathrm{C}\right)$ in the continuously agitated slurries. Water-saturated air or nitrogen purged the vapor space at $10 \mathrm{~mL} / \mathrm{min}$. A gas chromatograph analyzed benzene in syringe samples of the exit gas. Simulant slurries $(100 \mathrm{~mL})$ sealed under air in steel vessels ( $150 \mathrm{~mL}$ internal volume) simulated the processing tank. These were unstirred and incubated in an oven $\left( \pm 1^{\circ} \mathrm{C}\right)$. Personnel agitated the vessels by hand prior to syringe sampling through a septum port.

\section{REFERENCES}

1. L.-M. Lee and L. L. Kilpatrick, A precipitation process for supernate decontamination, DP-1636, E. I. du Pont De Nemours, Aiken, South Carolina (November 1982).

2. H. D. Martin, M. A. Schmitz, M. A. Ebra, D. D. Walker, L. L. Kilpatrick, and L.-M. Lee, In-tank precipitation process for decontamination of water soluble radioactive waste, Proc. Symposium on Waste Management 1:91-296 (1984).

3. P. D. d'Entremont and D. D. Walker, Tank farm processing of high-level waste for the defense waste processing facility, Proc. Symposium on Waste Management 2:69-73 (1987).

4. D. D. Walker and E. L. Wilhite, Soluble high-level waste decontamination and disposal at the savannah river site, Proc. First Annual International High-Level Radioactive Waste Management Conference 2:1110-1114 (1990).

5. A. K. Gupta, R. J. Hanrahan, and D. D. Walker, Radiolysis of sodium and potassium tetraphenylborate in aqueous systems, J. Phys. Chem., 95(9):3590 (1991).

6. A. K. Gupta, R. J. Hanrahan, and D. D. Walker, Use of co-60 gamma irradiation to simulate decomposition of tetraphenylborate precipitates from high level radioactive waste, Radiochim. Acta, 60:43 (1993).

7. C. L. Crawford, M. R. Gholami, R. N. Bhave, and R. J. Hanrahan, Pulse radiolysis of aqueous solutions of sodium tetraphenylborate, Radiat. Phys. Chem., 44:309 (1994).

8. M. J. Barnes, Decomposition of tetraphenylborate, Proc. Symposium on Waste Management, 1:759-762 (1991).

9. H. Flaschka and A. J. Barnard, Jr., Tetraphenylboron as an analytical reagent, Adv. Anal. Chem. Instr., 1:1-117 (1960). 